\title{
A Legal Analysis of the Nebulous Concept of Childhood in Nigeria
}

\author{
M. A. AjaNwachuku \\ Faculty of Law, Ebonyi State University, Abakaliki, Nigeria \\ Email: majanwachuku@yahoo.com
}

Received 3 May 2016; accepted 3 June 2016; published 6 June 2016

Copyright (C) 2016 by author and Scientific Research Publishing Inc.

This work is licensed under the Creative Commons Attribution International License (CC BY). http://creativecommons.org/licenses/by/4.0/

c) (i) Open Access

\begin{abstract}
The legal concept of childhood is a tinker for the application of different principles in diverse aspects of law including criminal law, contract, property law, family law and even international law. However, this concept has remained a puzzle because of its lack of uniformity in Nigerian domestic jurisdiction. Childhood is characterised differently in legal instruments depending on the purpose of the particular law. This paper analyzed the concept within Nigerian domestic legal system with the view of reconciling the different provisions on the determination of childhood and ascertaining the most probable stage of distinction between childhood and adulthood under Nigerian law. The paper concluded that despite the legal pluralism in Nigeria and the nebulous concept of childhood within the vast body of rules applicable in the country, it is possible to find a synthesis of these norms under the Child's Rights Act in the definition of childhood.
\end{abstract}

\section{Keywords}

\section{Childhood, Customary Law, Statutory Provisions, Nigeria}

\section{Introduction}

There are different stages of life, including childhood, adulthood and old age. In law, the relevance of determination of any of these stages is, amongst other things, to ascertain the benchmark of appraising conduct of persons, or capacity or expectations thereof. The benchmark of responsibility for persons at the lower pedestal of life (childhood) is lesser than persons who have attained adulthood, by virtue of the fact of mental development and capacity. However, the determination of the exact period of childhood is still shrouded in controversy in Nigerian law. Different legal instruments in Nigeria provide differently for "who the child is", in terms of the age limitation and capacity to act or to be held responsible. In fact, the concept of childhood is nebulous in the Nigerian legal system. This paper attempts to unravel this paradox and knit together the different applicable 
norms to arrive at a consensus position of the law. The paper thus examines both customary and statutory norms, and case law to arrive at the position applicable to all aspects of law in the legal system.

\section{Legal Determination of Childhood in Nigeria}

Childhood in common English parlance means the state or period of being a child. ${ }^{1}$ This definition rather than define the "child" abdicated the task to be determined by another process. The definition of childhood is therefore coterminous with the definition of a child. The position however, appears to be that childhood is the early period in the development of a person, which is suggestive of immaturity, and marked by innocence, trust and ingeniousness. ${ }^{2}$ It is characterized principally by the "undeveloped" state of mind of a person, which accounts for the readiness of the society to accept and tolerate the excesses, failures and inadequacies of the person. However, the legal concept of childhood is not defined by the psychological development of the person as much as his physical development. Thus, in the early case of Labinjoh $v A_{b a k e^{3}}$ a person ceases to be a child on the attainment puberty under Nigerian customary law. Under the Nigerian Child's Rights Act (2010), a person ceases to be a child on attaining the age of 18 years, which connotes a period of physical maturity.

The determination of the legal concept of a "child" therefore, is the task of the law-provider- the legislature, especially in a formal system of organized society. In such setting, the age at which a person is declared an adult and therefore legally responsible is the prerogative of the law. Below that age, a person is a child. In the informal setting, childhood is determined by the customary norms of the people. The Nigerian legal system is characterized by the application of both statutory and customary law, which makes it a legal pluralist system. Thus, under customary laws in Nigeria, ${ }^{4}$ the informal system of social control renders the determination of childhood by age almost ineffective; age is not generally, a symbol of capacity in the customary setting. Childhood under the different customary laws in Nigeria is determined by circumstance rather than age. ${ }^{5}$ This makes childhood under Nigerian customary laws at best, an amorphous concept. Different criteria are utilized to determine childhood under customary law. Mental capacity is one of such criterion, which relates to sanctions for customary crimes and civil wrongs. This is determined by the ability of the concerned person to confront and solve problems directly without the supervision of an adult. ${ }^{6}$ A person is presumed to have attained adulthood if he is mentally and socially able to solve problem pertaining to issues of life without supervision. Such a person can be held responsible for violation of customary norms or commission of crimes.

Other criteria for adjudging a person a child under customary law relates specifically to issues of devolution of property and symbol of authority other than determination of wrongful conduct. Different criteria such as financial independence, ${ }^{7}$ marriage, ${ }^{8}$ and initiation into age grade ${ }^{9}$ may determine childhood in majority of these circumstances under customary law in Nigeria. In most parts of the South Eastern Nigeria for instance, the first male child of the family is deemed to remain in childhood under customary law notwithstanding his age until the death of his father. Such persons are treated as children as long as their fathers are alive. ${ }^{10}$ However, a survey of the different customary laws by the Nigerian Institute of Advanced Legal Studies reveals that this position may be different in other parts of Nigeria, because it is shown that in some customs childhood stops at the age of ni-

\footnotetext{
${ }^{1}$ Webster's New Encyclopedia Dictionary (2002), (Massachusetts: Federal Street Press, 2002) p. 310.

${ }^{2}$ Ibid.

${ }^{3}(1924) 5$ NLR 33.

${ }^{4}$ Customary Law is also known as native law and custom in Nigeria. It is applicable in the Nigerian legal system as the law that was in force in Nigeria before colonisation and the reception of English laws in 1863. The application of English Law did not abrogated customary law in Nigeria. Both exist side by side as laws applicable in Nigeria. However, any customary law that is repugnant to natural justice, equity and good conscience or incompatible with any English law or that is contrary to public policy is avoided. Such customary law is said to have failed the repugnancy, incompatibility and public policy test known as validity tests. For more details, see Obilade, The Nigerian Legal System, (London: Sweet \& Maxwell, 1979), pp. 69-81, 100-110; Okonkwo (1980), Introduction to Nigerian Law, (London: Sweet \& Maxwell, 1980) pp. 1-8, 41-46; Park (1981), The Sources of Nigerian Law, (London: Sweet \& Maxwell, 1981), pp. 14-42, 65-82 and Odike \& AjaNwachuku (2008), Fundamentals of Nigerian Legal Methods, (Enugu: Tink Graphics, 2008) pp. 29-34, 38.

${ }^{5}$ Obilade (1979), Ibid., p. 83; Okonkwo (1980), Ibid., p. 41; Labinjoh v. Abake (1924) 5 NLR p. 33.

${ }^{6}$ See Oloko (1986), “Introduction: Protection and Violation of Child Right in Nigeria”, in UNICEF, Child Protection in Nigeria: Summary of Research Findings on Protection and Violation of Children's Rights, (Lagos: Jeromelaiho \& Associates Ltd,) p. 1.

${ }^{7}$ See Ayua and Okagbue (1996), The Rights of the Child in Nigeria, (Lagos: Nigerian Institute of Advanced Legal Studies, 1996) p. 30. See also Onibokun (1986), “Child Protection Measures: Review of Policies and Laws Protecting Children from Abuse in Nigeria”, in UNICEF, Child Protection in Nigeria: Summary of Research Findings on Protection and Violation of Children's Rights, (Lagos: Jeromelaiho \& Associates Ltd), p. 47.

${ }^{8}$ Onibokun, ibid.

${ }^{9}$ Ayua and Okagbue (1996), Op. cit.

${ }^{10}$ In the case of Owonyin v Omotosho (1961) 1 ANLR 304 at 309, Bairamian F.J described it as “a mirror of accepted usage".
} 
neteen, while in other customs it stretches up to twenty-nine years. ${ }^{11}$

The Customary Courts are empowered in Nigeria, to determine all questions of native law and custom including the issue of childhood, if the determination thereof relates to a legal problem brought before it. The Court usually applies the customary law of the area in which it is situated, where the dispute arose. Such courts do not have difficulty in ascertaining the customary law of the area because the presiding officers are usually natives of the area where the courts is situated who are vast in the customs of the area. ${ }^{12}$ However, customary law as to the determination of childhood may also be proven by judicial notice ${ }^{13}$ or traditional expert evidence of persons who are vast in the native law and custom of the area. ${ }^{14}$ Judicial precedent is seldom utilized because of the flexible nature of customary law and the differences in the native laws and customs applicable in Nigeria. But where the legal precedent is within the same native law and custom as the matter before the court, the court is obliged to apply precedent to decide the question before it, until there is evidence to prove that the custom has changed. Thus, for instance, the court in the case of Labinjoh v. Abake $e^{15}$ has held that childhood ceases at the attainment of puberty in the Yoruba native law and custom. In that case, the defendant (a girl aged about 18 years and still living with her parent) bought some goods for trading purposes from the plaintiff. The plaintiff sued for the sum of $£ 48: 18^{\mathrm{s}}: 8^{\mathrm{d}}$ being the value of the goods sold and supplied to the defendant. The defendant resisted the suit arguing that she was an infant and by virtue of the provisions of the Infants Relief Act, 1874 (a statute of general application), she was not bound to pay since the contract was for trading purposes and not for necessaries. The Police Magistrate Court sitting at Lagos agreed with the defendant and dismissed the plaintiff's claim, reasoning that since the Act applied and did not define an infant, an infant for the purpose of contract should be ascribed the meaning of a person below 21 years as under the common law. The plaintiff appealed to the Divisional Court (an equivalent of High Court), that the transaction was not governed by the Act but by customary law (since both parties were natives) and that the defendant was liable to pay, being an adult for reason of having attained puberty. The court held that the Act was applicable but that since the Act did not state who an infant is, the test to determine the issue should be under customary law i.e. a person who has not attained puberty. The court entered judgment for the plaintiff because the defendant had attained puberty. The defendant appealed to the Full Court (equivalent of Supreme Court) that gave a unanimous judgment remitting the case to the trial court to find out whether there was any native law and custom applicable to the subject matter of litigation and if so, what the customary law was. The point of emphasis in this Full Court did not overrule the decision of the Divisional Court that infancy or childhood ceases on attainment of puberty under customary law in Nigeria. ${ }^{16}$ Although, this decision has gone a long way to clarify the notion of childhood under Nigerian customary law, it did not solve the problem of lack of common definition of the concept under all native laws and customs in Nigeria. This is in addition to the fact that the criterion of "puberty" as a yardstick for determining adulthood is variable, depending on individual development and sex of the person.

Like customary law, statutory law is also largely abstruse on the question of childhood in Nigeria. Under statutory law, childhood is variously constituted depending on the focus of the particular law and the circumstances of each case. Under the Criminal Code Act (2010) ${ }^{17}$ for instance, childhood is delimited for the purpose of conviction for unlawful carnal knowledge to the age of 12 years. ${ }^{18}$ Any male person below that age, in the eyes of the law is incapable of having carnal knowledge, more so unlawfully. ${ }^{19}$ Section 30 of the same Act adopted the "capacity criteria” of determining childhood in respect of the commission of any crime other than "unlawful

\footnotetext{
${ }^{11}$ O. M. Onibokun, Loc. cit.

${ }^{12}$ In some states of Nigeria e.g. Ebonyi State (where the author resides), lawyers are Chairmen of the customary courts. They preside and ensure that the court is guided aright on issues of law and procedure. These lawyers need not be natives of the communities where the courts are situated, but are usually from that neighbourhood. For the members of the customary courts, they are usually natives of the communities where the courts are situated and they know the customary law of the area. For a person to be appointed a member of a customary court in Ebonyi State he must inter alia have "wide knowledge of the customary law and usages prevailing in the area of jurisdiction of that court". See Ebonyi State Customary Court Law Cap. 47, Laws of Ebonyi State of Nigeria, 2009.

${ }^{13}$ See sections 122(1) and 124(1) of the Evidence Act of Nigeria, 2011.

${ }^{14}$ See section 14 Evidence Act.

${ }^{15}$ (1924) 5 NLR 33, ("native law and custom decrees that persons come of age when they reach the age of puberty").

${ }^{16}$ Emphasis supplied.

${ }^{17}$ Section 30, Cap. C. 38, Laws of the Federation of Nigeria, 2010. This is the principal code on crime in the Southern part of Nigeria, comprised of the States of: Abia, Akwa-Ibom, Anambra, Bayelsa, Cross River, Delta, Ebonyi, Edo, Ekiti, Enugu, Imo, Lagos, Ogun, Ondo, Osun, Oyo and Rivers

${ }^{18}$ Ibid, section 357

${ }^{19} \mathrm{Ibid}$, section 30 . This presumption is irrebuttable, so that it is immaterial that it is proven that at the time he committed the offence, he knew that he was committing an offence and or was committing an act that was morally wrong, improper and condemnable. A legally responsible male in such circumstances may be convicted of the lesser offence of indecent assault under section 360 of the Code.
} 
carnal knowledge” by a person under the age of 12 years. It provides that where the circumstance is the commission of any other offence, a male person under the age of 12 years cannot be convicted of the offence if it has not been proved that at the time of committing the offence, "he had the capacity to know that he ought not to commit it". The word "capacity" is not explained in the provision nor is it interpreted in the Act. It may however, be interpreted to mean that a person of twelve years or below had the mental ability to know that he ought not to do the act because it is an offence, or that he had the mental ability to know that the act was wrong, improper and condemnable to do. Notwithstanding, the abandonment of age for mental capacity in the determination of childhood in this provision introduces speculative elements for the application of legal norms relating to the question of childhood, which further convolutes the concept under Nigerian statutory law.

The Penal Code $(1963)^{20}$ on the other hand, delimits childhood by age other than circumstances. The Code provides, for the purpose of conviction for an offence that childhood ceases at the age of 7 years. ${ }^{21}$ Thus, a person who commits an offence and is shown to be above 7 years is criminally liable to trial and conviction under the Code applicable in the northern part of Nigeria. Outside of the two Codes, other statutes in civil matters also provide for determination of childhood by age rather than circumstances. For instance, section 59(2) of the Nigerian Labour Act $(2010)^{22}$ provides for the purpose of employed in Nigeria that a person under the age of 14 years cannot be employed or allowed to work in any industrial undertaking. Even though, a proviso in the section allows such a person to work in the prohibited sector of industrial undertaking or technical schools under supervision by the Ministry of Education or corresponding Department of Government of a State, this does not introduce a new criteria of determination by circumstance. Supervision of a person in the circumstances mentioned in the Act confirms the presumption of the mental capacity of the person as a child by the law.

The Child's Rights Act 2003, ${ }^{23}$ which is the comprehensive enactment on children's rights in Nigeria, describes a child as a person below the age of 18 years. ${ }^{24}$ It appears that this Act has finally settled the statutory differences on the issue of childhood in Nigeria. This is so for several reasons. First, the Act is a federal legislation, which directly borders on the rights of the child in Nigeria. Therefore, the legislature must have taken into consideration the provisions on the limits of childhood in the different legal instruments before enacting the Act to protect the child from abuse. Secondly, as a federal legislation enacted within the concurrent legislative powers of the National Assembly, the Act takes precedence over states legislations on the same legislative matter; this is the doctrine of covering the field. Any state legislation on the definition of a child for the purpose of application of principles of law that is inconsistent with the Child's Right Act may be void and inapplicable. Thirdly, many state legislative houses in Nigeria have adopted the Child's Right Act into state law, thereby bringing the application of the Act into force in such states.

\section{Conclusion}

This paper has identified the different definitions of the "child" under Nigerian law. It observed that the concept of childhood is constituted differently under both customary and statutory laws, and within statutory provisions in Nigeria. The law is divided on the criteria of determination of childhood-whether by age or by circumstances. There is therefore no uniform upper age limit under either customary law or statutory law in Nigeria. The paper concludes that the Child's Rights Act is better positioned to reconcile the ambiguity of the demarcation between childhood and adulthood in Nigeria, in view of the legal consequence of the varied determination of the age of maturity under different aspects of Nigerian law.

\section{References}

Ayua, I. A., \& Okagbue, I. (1996). The Rights of the Child in Nigeria (p. 30). Lagos: Nigerian Institute of Advanced Legal Studies.

Child's Rights Act (2010). Cap. C.50, Laws of Federation of Nigeria, Section 277.

Criminal Code Act (2010). Cap. C.30, Laws of the Federation of Nigeria, Section 30, Section 257 and Section 360.

\footnotetext{
${ }^{20}$ Section 50(a) of Cap 89, Laws of Northern Nigeria, 1963. This is the principal Code on crime in the Northern part of Nigeria, comprised of the States of: Adamawa, Bauchi, Benue, Borno, Gombe, Jigawa, Kaduna, Kano, Katsina, Kebbi, Kogi, Kwara, Nasarawa, Niger, Plateu, Sokoto, Taraba, Yobe, Zamfara and Abuja (the Federal Capital Territory).

${ }^{21}$ Ibid.

${ }^{22}$ Cap. L. 1, Laws of the Federation of Nigeria, 2010.

${ }^{23}$ Cap C. 50, Laws of the Federation of Nigeria, 2010.

${ }^{24} \mathrm{Ibid}$, section 277.
} 
Ebonyi State Customary Court Law (2009). Cap. 47, Laws of Ebonyi State of Nigeria, 935-962.

Evidence Act of Nigeria (2011). Sections 14,122 (1) and 124 (1).

Labinjoh v. Abake (1924). 5NLR p.33.

Labour Act (2010). Cap. L. 1, Laws of Federation of Nigeria, Section 59 (2).

Obilade, A. O. (1979). The Nigerian Legal System (pp. 69-81, 100-110). London: Sweet \& Maxwell.

Odike, E. A., \& Ajanwachuku, M. A. (2008). Fundamentals of Nigerian Legal Methods (pp. 29-24, 38). Enugu: Tink Graphic.

Okonkwo, C. O. (1980). Introduction to Nigerian Law (pp. 14-42, 65-82). London: Sweet \& Maxwell.

Oloko, S. B. A. (1986). Introduction: Protection and Violation of Child Right in Nigeria. In: UNICEF, Child Protection in Nigeria: Summary of Research Findings on Protection and Violation of Children's Right (p. 1). Lagos: Jeromeiho \& Associates Ltd.

Onibokun, O. M. (1986). Child Protection Measures: Review of Policies and Laws Protecting Children from Abuse in Nigeria. In UNICEF, Child Protection in Nigeria: Summary of Research Findings on Protection and Violation of Children's Rights (p. 47). Lagos: Jeromelaiho \& Associates Ltd.

Owonyin v. Omotosho (1961). 1 ANLR p.304 at p.309.

Park, A. E. W. (1981). The Sources of Nigerian Law (pp. 41-42, 55-52). London: Sweet \& Maxwell.

Penal Code (1963). Cap 89, Laws of Northern Nigeria, Section 50 (a).

Webster’s New Encyclopedia Dictionary (2002). Massachusetts: Federal Street Press, 310. 